\title{
アスコルビン酸脂肪酸エステルの抗菌作用
}

(昭和 63 年 5 月 9 日受理)

加藤祥子*1 小林 寿*1 渡辺忠雄*2

\section{Antibacterial Action of Ascorbic Fatty Acid Esters}

Sachiko Kato*1, Hisashi Kobayashi*1 and Tadao Watanabe*2

$\left({ }^{* 1}\right.$ Department of Food and Nutrition, College of Nakamuragakuen: 5-7-1, Befu, Jōnan-ku, Fukuoka, Japan; ${ }^{* 2}$ Torigoe Flour Milling Co., Ltd.: $6-5-2$,

Hakozakifutō, Higashi-ku, Fukuoka, Japan)

\begin{abstract}
Antibacterial and antioxidative actions of ascorbyl caprate (AC), ascorbyl laurate (AL), ascorbyl myristate (AM) and ascorbyl palmitate (AP) synthesized by the authors and also ascorbyl stearate (AS) obtained commercially were investigated.

$\mathrm{AC}, \mathrm{AL}$ and $\mathrm{AM}$ showed antibacterial activity against B. subtilis and $S$. aureus, but $\mathrm{AP}$ and AS did not. None of the esters, on the other hand, had such action against $E$. coli, but AC displayed antibacterial activity against $E$. coli when sodium hexametaphosphate (HP) was added at the same time, and the combination of $0.2 \% \mathrm{HP}$ and $0.4 \% \mathrm{AC}$ showed bactericidal activity against $E$. coli.
\end{abstract}

Antioxidative activities of $\mathrm{AC}, \mathrm{AL}, \mathrm{AM}$ and $\mathrm{AP}$ were as potent as that of $\mathrm{AS}$.

(Received May 9, 1988)

Key words：抗菌作用 antibacterial action; アスコルビン酸脂肪酸エステル ascorbic fatty acid ester; 大腸菌 Escherichia coli; 併用効果 combined effect；抗酸化作用 antioxidative action; ヘキサメタリン酸 hexametaphosphate

食品保存のための保存料使用は多くの問題をかかえて いるとはいえ，現実にはその使用を全く否定してしまう ことはできない，著者らは，保存料開発の一手段として 既存の食品添加物についてその抗菌作用を検討した。 そ の結果, 現在乳化剤として使用されているモノグリセリ ドやショ糖脂肪酸エステルは, いずれも脂肪酸エステル であるが，グラム陽性菌に抗菌作用を示し，さらに縮合 リン酸塩を併用することにより，E.coli のようなグラム 陰性菌に対しても抗菌作用を示すことがわかった ${ }^{1) \sim 5)}$. そこで同じく脂肪酸エステルであるアスコルビン酸脂肪 酸エステルの中にも抗菌作用之抗酸化作用を併有する化 合物があるのではないかと考え, 数種のアスコルビン酸 脂肪酸エステルを合成し，これらについて抗菌作用並び に抗酸化作用を検討したので, その結果について報告す る.

*1 中村学園大学食物栄養学科：福岡市城南区別府 5-7-1

*2 島越製粉株式会社：福岡市東区箱崎子頭 6-5-2

\section{実験材料並びに方法}

1. 試 薬 類

アスコルビン酸脂肪酸エステルは食品添加物公定書解 説書 ${ }^{6} に$ 準じて合成を行った. すなわち，L-アスコルビン 酸之脂肪酸を濃硫酸に溶かし，室温で 20 時間放置して エステル化を行った後, 砕水中に注ぎ析出した結晶をエ ーテルで抽出し精製を行った. 合成したエステルとその 融点は次のとおりであった。

L-アスコルビン酸カプリン酸エステル（以後 $\mathrm{AC}$ と

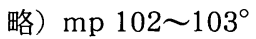

L-アスコルビン酸ラウリン酸エステル（AL と略） $\mathrm{mp}$ $107 \sim 108^{\circ}$

L-アスコルビン酸ミリスチン酸エステル（AM と略） $\operatorname{mp} 110 \sim 111^{\circ}$

L-アスコルビン酸パルミチン酸エステル（AP と略） $\operatorname{mp~} 113 \sim 115^{\circ}$

なお，合成したエステルはいずれも純度 $95 \%$ 以上で あった。

L-アスコルビン酸ステアリン酸エステル（和光純薬工 
Table 1. Minimum Inhibitory Concentration of Ascorbic Fatty Acid Esters on the Growth

\begin{tabular}{lccc}
\hline & \multicolumn{3}{c}{ MIC (\%) } \\
\cline { 2 - 4 } Ester & B. subtilis & S. aureus & E. coli \\
\hline AC & 0.1 & 0.06 & $0.4<$ \\
AL & 0.02 & 0.03 & $0.4<$ \\
AM & 0.03 & 0.02 & $0.2<$ \\
AP & $0.1<$ & $0.1<$ & $0.1<$ \\
AS & $0.1<$ & $0.1<$ & $0.1<$ \\
\hline
\end{tabular}

AC : ascorbyl caprate

$\mathrm{AL}$ : ascorbyl laurate

AM : ascorbyl myristate

AP : ascorbyl palmitate

AS : ascorbyl stearate

業(株)製，AS と略）

ショ糖カプリン酸エステル（SC と略）は Osipow ら の方法 ${ }^{7)}$ で合成し，大竹の方法息に準じてシリカゲルカラ ムを通したモノエステル部を使用した。

縮合リン酸塩としてへキサメタリン酸ナトリウム（ポ リホス化学(株)製, HP と略) を, その他は市販特級品む しくは一級品を用いた.

\section{2. 供 試 菌}

Bacillus subtilis IFO 3007

Staphylococcus aureus IFO 3060

Escherichia coli IFO 3301

\section{3. 培 地}

エールリッヒ肉エキス（極東製薬工業(株)製） $10 \mathrm{~g}$ と ポリペプトン（大五栄養化学(株)製） $10 \mathrm{~g}$ を精製水 $1,000 \mathrm{ml}$ に溶かし $\mathrm{pH}$ を 7.0 に調整し， $1 \%$ 肉エキスブ イヨン培地とした. なお, 生菌数を測定する場合は上記 ブイヨン培地に $1.5 \%$ の寒天を加えて用いた。

\section{4. 抗菌力の測定}

供試菌を $1 \%$ 肉エキスブイヨン培地中で $30^{\circ} 17$ 時間 振盪培養した後, 同培地中で波長 $660 \mathrm{~nm}$ における吸光 度 $\left(\mathrm{OD}_{660}\right)$ を 0.3 に調整して菌液とした. エステルある いはHP を設定濃度になるように溶かした培地 $9.5 \mathrm{ml}$ に上記菌液 $0.5 \mathrm{ml}$ を加え $30^{\circ}$ で振盪培養を行い, $\mathrm{OD}_{660}$ の増加加ら菌の増殖を判定した. $\mathrm{OD}_{660}$ の測定は東京光 電(株)製の光電比色計 Type I 型を用いた.

\section{5. 抗酸化力測定}

抗酸化力の測定は, 各エステルを大豆油（和光純薬工 業(株)製) に添加後 $37^{\circ}$ 恒温器中に静置し, 経時的に過 酸化物価 (POV) を測定した. POV の測定は食品衛生検 查指針 I ${ }^{9}$ の方法を用いた. すなわち, 試料油にヨウ化力 リウム溶液を加え暗所に 5 分間放置後, 遊離したヨウ素 を $0.01 N$ チオ硫酸ナトリウム溶液で滴定した.

また別にリノール酸の自動酸化に対する抗酸化力測定 を行った. すなわち， $0.1 M$ リノール酸のエタノール溶
Table 2. Combined Effect of Ascorbic Fatty Acid Esters and HP on the Growth of $E$. coli

\begin{tabular}{llclll}
\hline \hline & & \multicolumn{4}{c}{ Growth $\left(\mathrm{OD}_{660}\right)$} \\
\cline { 3 - 6 } Ester & $(\%)$ & \multicolumn{4}{c}{$\mathrm{HP}(\%)$} \\
\cline { 3 - 6 } & & 0 & 0.1 & 0.2 & 0.5 \\
\hline \multirow{2}{*}{ Control } & 0 & 0.43 & 0.37 & 0.37 & 0.34 \\
AC & 0.2 & 0.46 & 0.12 & 0 & 0 \\
& 0.4 & 0.34 & 0 & 0 & 0 \\
AL & 0.2 & 0.49 & 0.49 & 0.46 & 0.36 \\
& 0.4 & 0.52 & 0.41 & 0.44 & 0.28 \\
AM & 0.2 & 0.36 & 0.40 & 0.34 & 0.34 \\
\hline
\end{tabular}

HP: sodium hexametaphosphate

液 $5 \mathrm{ml}$, 各エステルのエタノール溶液 $0.5 \mathrm{ml}$ を $0.1 M$ リン酸緩衝液 $(\mathrm{pH} 7.0)$ で $25 \mathrm{ml}$ 定容とし, $37^{\circ}$ 恒温器内 に放置後経時的に過酸化物量を測定した。過酸化物量の 測定は満田らのロダン鉄法 ${ }^{10)}$ を用いた。 すなわち，試料 溶液 $0.1 \mathrm{ml}$ に $75 \%$ エノール $4.7 \mathrm{ml}, 30 \%$ チオシアン 酸アンモニウム $0.1 \mathrm{ml}, 0.02 M$ 塩化第一鉄 $0.1 \mathrm{ml}$ を加 え発色させ， 3 分後に $\mathrm{OD}_{500}$ を測定した.

なお，エステルの終濃度はいずれも $0.01 \%$ とした。

\section{実験結 果}

\section{1. 最小発育阻止濃度 (MIC)}

培養開始前と 24 時間培養後の $\mathrm{OD}_{660}$ の差が 0.03 末 満の場合を発育阻止とした. その結果, B. subtilis, S. aureus に対して AC, AL, AM は抗菌作用を発揮したが, AP, AS は抗菌作用を示さなかった. 一方，E.coli に対 してはすべてのエステルが抗菌作用を示さなかった (Table 1).なお, 各エステルの培地に対する溶解性から エステルの最高濃度を $\mathrm{AC}, \mathrm{AL}$ は $0.4 \%, \mathrm{AM}$ は $0.2 \%$, $\mathrm{AP}, \mathrm{AS}$ は 0.1\%とした.

\section{E. coli に対するエステルと HP の併用効果}

モノグリセリドが HP 共存下において E. coli に対し て抗菌作用を発揮している2)ので，アスコルビン酸脂肪 酸エステルとHP の併用効果を検討した (Table 2). そ の結果, $\mathrm{AC}$ は E . coli に対し抗菌作用を発現したが $\mathrm{AL}$ 並びに AM は抗菌作用を示さなかった.すなわち， 0.4\% AC 単独ではほとんど抗菌作用を示さなかったが, $0.1 \% \mathrm{HP}$ を併用することにより抗菌作用を示すことが 分かった。さらに, $0.2 \% \mathrm{HP}$ を併用したときは, $\mathrm{AC}$ 濃 度を $0.2 \%$ にげても抗菌作用を示した. また, Table 3 に示したとおり， $\mathrm{AC}$ のみを添加したとき，無添加のと きより経日的に吸光度を増した。 しかもその増加は $\mathrm{AC}$ 濃度が高いほど著しかった. また，この際培地は着色し てきた。 $0.4 \% \mathrm{AC}$ と 0.1 あるいは $0.2 \% \mathrm{HP}$ を併用した とき 5 日後においても E. coli の増殖は認められなかっ た. そこで， $\mathrm{AC}$ とP を併用したときの生菌数を測定 した (Table 4). その結果， 0.2 あるいは $0.4 \% \mathrm{AC}$ と 
$0.2 \%$ HP を併用したとき生菌数の減少が認められた。 特に $0.4 \% \mathrm{AC}$ と $0.2 \% \mathrm{HP}$ を併用したとき生菌数の急 激な減少が起こり，3 時間後にはほとんど生菌は認めら れなくなった。

\section{3. 緩衝液中における $E$. coli に対する脂肪酸エステ ルの作用}

E. coli に対する AC の作用及び培養中の着色の原因を 知るため，培地成分を含まない E. coli の䯚濁液に脂肪 酸エステルを作用させた。すなわち， $0.1 M$ リン酸緩衝 液 $(\mathrm{pH}$ 7.0) に懸濁した E. coli に AC 溶液を設定濃度に なるように加え， $30^{\circ}$ 恒温に保ち経時的にその $\mathrm{OD}_{660}$ を 測定した。同時にSCについても行った，その結果 Fig. 1 に示したように，いずれの場合も $\mathrm{OD}_{660}$ の減少が認め られた。しかも $\mathrm{AC}$ 溶液中での $\mathrm{OD}_{660}$ の減少は $\mathrm{SC}$ 溶液 中より著しかった。 また，Fig. 2 に示したように AC 濃 度が高いほどその減少は大きく， $0.4 \% \mathrm{AC} に 0.2 \% \mathrm{HP}$ を併用したときはさらに著しい減少を示した。このと き，溶液の着色は認められなかった。

Table 3. Combined Effect of AC and HP on Growth of E. coli

\begin{tabular}{lllllll}
\hline \hline & & \multicolumn{5}{c}{ Growth $\left(\mathrm{OD}_{660}\right)$} \\
\cline { 3 - 7 } AC (\%) & HP (\%) & \multicolumn{5}{c}{ Incubation time (day) } \\
\cline { 3 - 7 } & & 1 & 2 & 3 & 4 & 5 \\
\hline \multirow{2}{*}{0} & 0 & 0.40 & 0.48 & 0.46 & 0.46 & 0.45 \\
& 0.1 & 0.31 & 0.33 & 0.30 & 0.27 & 0.25 \\
& 0.2 & 0.27 & 0.29 & 0.26 & 0.21 & 0.18 \\
0.1 & 0 & 0.35 & 0.49 & 0.63 & 0.65 & 0.61 \\
& 0.1 & 0.15 & 0.34 & 0.44 & 0.44 & 0.44 \\
& 0.2 & 0.07 & 0.25 & 0.34 & 0.39 & 0.38 \\
0.2 & 0 & 0.46 & 0.70 & 0.80 & 0.87 & 0.89 \\
& 0.1 & 0.12 & 0.42 & 0.63 & 0.66 & 0.68 \\
& 0.2 & 0 & 0.36 & 0.52 & 0.58 & 0.58 \\
0.4 & 0 & 0.34 & 0.63 & 0.77 & 0.86 & 0.91 \\
& 0.1 & 0 & 0 & 0 & 0 & 0 \\
& 0.2 & 0 & 0 & 0 & 0 & 0 \\
\hline
\end{tabular}

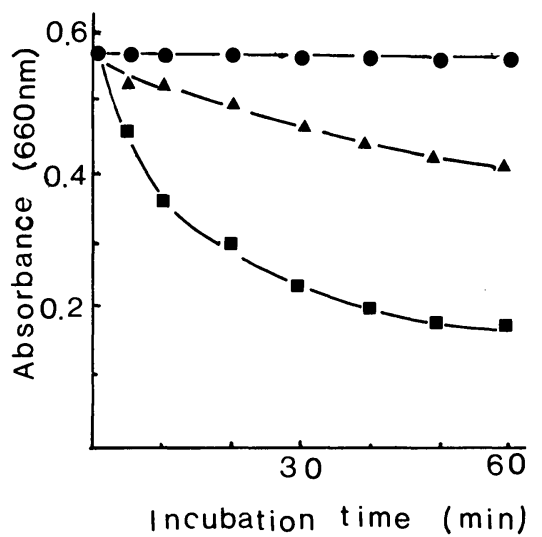

Fig. 1. Effect of AC or SC on E. coli $0.4 \% \mathrm{SC}$

SC: sucrose caprate

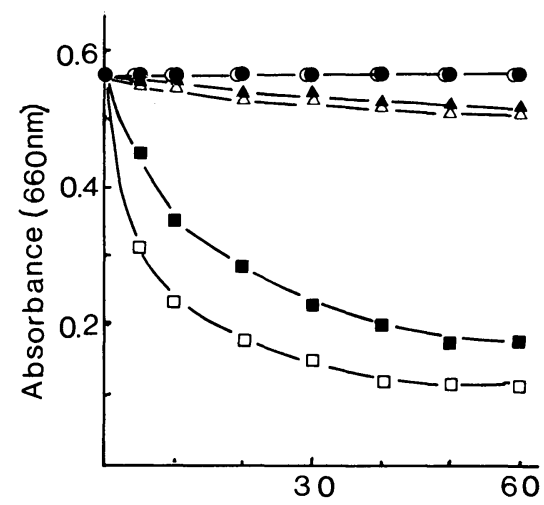

Incubation time (min)

Fig. 2. Synergistic effect of $\mathrm{AC}$ and $\mathrm{HP}$ on $E$. coli

- - control; - $\mathrm{O}-0.2 \% \mathrm{HP} ;-\mathbf{\Delta}-$ $0.2 \% \mathrm{AC} ;-\triangle-0.2 \% \mathrm{AC}+0.2 \% \mathrm{HP} ;-\mathbf{\square}-$ $0.4 \% \mathrm{AC} ;-\square-0.4 \% \mathrm{AC}+0.2 \% \mathrm{HP}$

Table. 4. Survival of E. coli Treated with AC and HP

\begin{tabular}{|c|c|c|c|c|c|c|c|}
\hline \multirow{3}{*}{$\begin{array}{l}\text { Treatment } \\
\text { (hr) }\end{array}$} & \multirow{3}{*}{$\frac{\mathrm{AC}(\%)}{\mathrm{HP}(\%)}$} & \multicolumn{6}{|c|}{ Viable cell count (cell/ml) } \\
\hline & & \multicolumn{2}{|c|}{0} & \multicolumn{2}{|c|}{0.2} & \multicolumn{2}{|c|}{0.4} \\
\hline & & 0 & 0.2 & 0 & 0.2 & 0 & 0.2 \\
\hline 0 & & $4.0 \times 10^{7}$ & $3.6 \times 10^{7}$ & $3.4 \times 10^{7}$ & $4.1 \times 10^{7}$ & $4.1 \times 10^{7}$ & $4.0 \times 10^{7}$ \\
\hline 1 & & $4.7 \times 10^{7}$ & $3.4 \times 10^{7}$ & $4.0 \times 10^{7}$ & $1.7 \times 10^{4}$ & $1.5 \times 10^{7}$ & $2.1 \times 10^{2}$ \\
\hline 3 & & $4.2 \times 10^{8}$ & $1.2 \times 10^{8}$ & $2.0 \times 10^{8}$ & $1.7 \times 10^{4}$ & $3.3 \times 10^{7}$ & $3>$ \\
\hline 6 & & $5.5 \times 10^{8}$ & $3.2 \times 10^{8}$ & $1.1 \times 10^{8}$ & $1.0 \times 10^{3}$ & $7.1 \times 10^{7}$ & 0 \\
\hline 24 & & $2.0 \times 10^{9}$ & $4.7 \times 10^{8}$ & $1.8 \times 10^{8}$ & $3.3 \times 10^{2}$ & $2.1 \times 10^{8}$ & 0 \\
\hline
\end{tabular}

Medium: nutrient agar ( $\mathrm{pH} 7.0)$

Incubation: $37^{\circ} \mathrm{C} 24 \mathrm{hr}$. 


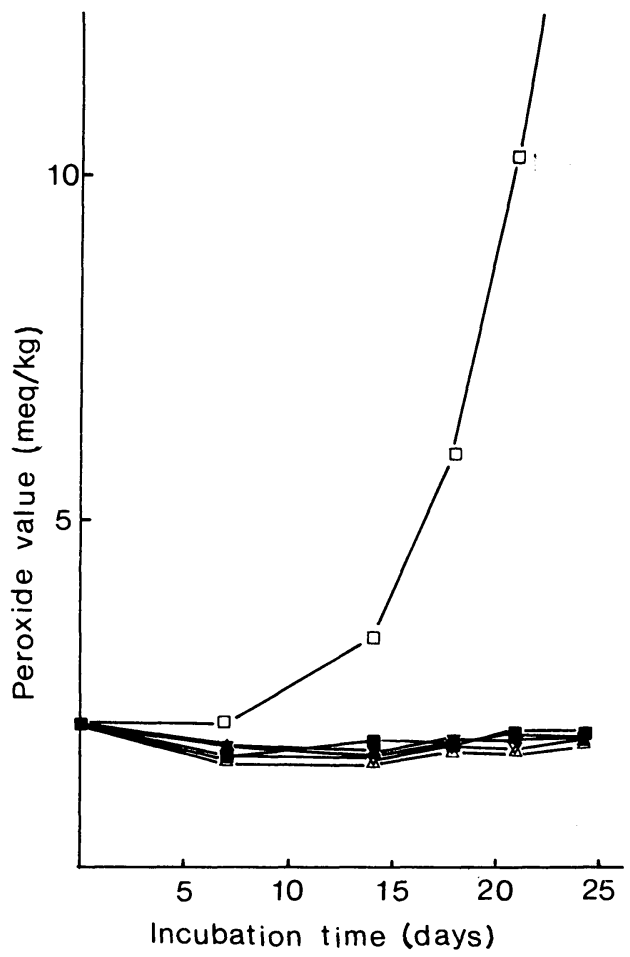

Fig. 3. Comparison of antioxidative activity of ascorbic fatty acid esters on soy bean oil $-\square-$ control; $-\triangle-\mathrm{AC} ;-\nabla-\mathrm{AL}$; $-\Delta-\mathrm{AM} ;-\boldsymbol{\nabla}-\mathrm{AP} ;-\boldsymbol{\square}$ - AS

\section{4. 抗酸化作用}

大豆油にアスコルビン酸脂肪酸エステルを $0.01 \%$ 添 加してその抗酸化作用を検討した. その結果, Fig. 3 に 示したようにいずれのエステルも市販の AS に劣らぬ抗 酸化作用を示した。また，リノール酸を用いた抗酸化作 用においても，Fig. 4 に示したように大豆油の場合と同 様にいずれのエステルも市販の AS に劣らずリノール酸 の自動酸化を抑制した。

\section{考察}

乳化剂であるモノグリセリドやショ糖脂肪酸エステル の中には抗菌作用を有するものもある．強化剤である AS は油性食品の酸化防止剂として一般に利用されてい る. ASにも抗菌作用があればその利用価值はさらに拡 大するという考えに基づき， AS 並びにその同族体の抗 菌作用について検討した。

AC, AL, AM はB. subtilis 並びにS. aureus に対し有 効であったが，E. coliに対してはほとんど効果が認めら れなかった。しかし，HP と併用したときは ACのみが E. coli に対し抗菌作用を発現した. これらのことは，モ ノグリセリドやショ糖脂肪酸エステルがグラム陽性菌に 対してのみ有効であり，また，HP との併用により抗菌

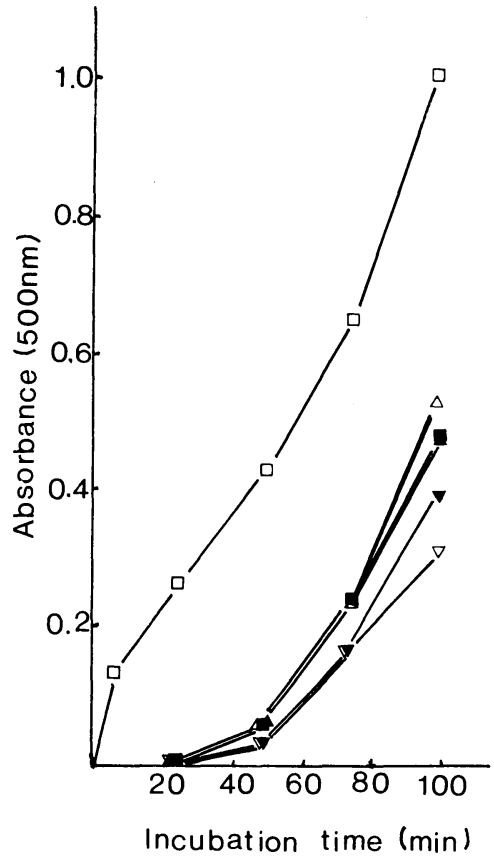

Fig. 4. Comparison of antioxidative activity of ascorbic fatty acid esters on linoleic acid $-\square-$ control; $-\triangle-\mathrm{AC} ;-\nabla-\mathrm{AL}$; $-\boldsymbol{\Delta}-\mathrm{AM} ;-\boldsymbol{\nabla}-\mathrm{AP} ;-\boldsymbol{\square}$ AS

性は拡大するが脂肪酸の炭素数に影響を受けるという報 告1), 2), 4) と同様で, 限られた炭素数のエステルのみが有効 であった. $0.4 \% \mathrm{AC}$ と 0.1 並びに $0.2 \% \mathrm{HP}$ を併用した とき, 5 日後む全く E. coli の増殖が認められず, 新培地 に移植しても菌の増殖が認められなかったし，また生菌 数を経時的に測定した結果でも生菌はほとんよ゙認められ ず，致死的に作用していることが分かった。

Table 3 において， $\mathrm{AC}$ を添加したときの $\mathrm{OD}_{660}$ が経 日的に増大し，このとき培地の着色が認められた。 しか し, E. coli の菌数測定の結果は AC 無添加のときとほと んど変わらなかった，従って，この吸光度の増大は培地 の着色によるものであって, E. coli の増殖によるもので ないことが分かった。 さらに，この着色現象は AC以外 に $\mathrm{AL}, \mathrm{AM}$ 添加のときも認められたが SC 添加では認 められず, また, E. coli を接種しない培地, E. coli を接 種しても AC， HP 共存下で致死的な作用を受けた培地 や E. coli と ACだけでは認められなかったことから, この着色現象には E. coli, 培地, アスコルビン酸エステ ルの 3 者が必要であると考えた。

AC, AL, AM, AP並びに AS はいずれも大豆油並びに リノール酸に対して抗酸化作用を示した。 綾野ら ${ }^{11}$ 並び に山口ら ${ }^{12}$ は，AS はラードに対し抗酸化力は示さない が，トコフェロールとの併用により相乗作用を示すと報 
告している，また，青山らのパーム油を使った報告 ${ }^{13)}$ はAS とトコフェロールの相乗性を認めていない。この ように AS とトコフェロールの相乗性については明確て はない，本実験においては，結果は示していないが使用 した大豆油中にはトコフェロールを含んでいたので，エ ステル類の大豆油に対する抗酸化力はエステルとトコフ ェロールの相乗作用による可能性も考えられる．また， 山口らはAS はリノール酸に対してはほとんど抗酸化力

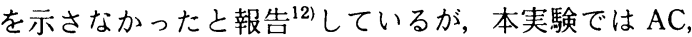
$\mathrm{AL}, \mathrm{AM}, \mathrm{AP}, \mathrm{AS}$ 共にリノール酸の自動酸化を抑制し た。いずれにしても AC, AL，AM 並びに AP は市販の AS に劣ら妨酸化力を発揮した。

以上の結果から, AC は単独でもE. coli から漏洩は引 き起こすが抗菌作用は示さない，しかし， AC は HPを 併用することによりグラム陰性菌である E. coli に対し 致死的に働くことが明らかになった。この併用効果をモ ノグリセリドあるいはコール酸と HP の E. coli に対す る併用効果の報告21.31. 14) と比較してみると， AC の作用 はかなり強力であると推論できる．AC は抗酸化力を有 し，水に対する溶解度もかなりあることから食品への利 用は大いに期待できると考える.

\section{要 約}

1. AC, AL, AM は B. subtilis, S. aureus に対し抗菌 作用を示したが E. coli に対しては抗菌作用を示さなか った.

2. AP, AS は B. subtilis, S. aureus, E. coli のいずれ に対しても抗菌作用を示さなかった。

3. AC は HP と併用することにより E. coli に対し抗 菌作用を発現した。

4. $0.4 \% \mathrm{AC}$ と $0.2 \% \mathrm{HP}$ の併用は E. coli に対し致死
的に働いた。

5. 合成した AC, AL, AM, AP はいずれも大豆油並び にリノール酸に対し市販の AS に劣らぬ抗酸化作用を示 した。

\section{文献}

1）加藤信之, 芝崎 勲; 䣫工. 53, 793 801 (1975).

2）堤 将和，安井紀久代，一色賢司，渡辺忠雄：食衛誌，18， $341 \sim 345$ (1977).

3）須田郁夫，宮山哲夫，須田真理，堤 将和，渡辺忠雄：食 衛誌. 23, 302 307 (1982)

4) 加藤祥子, 小林 寿; 中村学園研究紀要 $15,253 \sim 256$ (1982).

5）加藤祥子, 小林 寿, 渡辺忠雄：食衛誌，27，218２28 (1986).

6）石館守三，谷村顕雄監修：“第五版食品添加物公定書解説 書” D-18 (1987), 広川書店.

7) Osipow, L., Snell, F. D., York, W. C., Finchler, A.: Ind. Eng. Chem. 48, 1,459 1,464 (1956).

8）大竹俊樹：精糖技術研究会誌．12,25～34 (1963).

9）厚生省環境衛生局監修：“食品衛生検查指針” I . p. 351 (1973), 日本食品衛生協会.

10）満田久輝，安本教傳，岩見公和：栄養と食糧 19, 210 214 (1966).

11）綾野雄幸, 古橋樹雄, 渡辺幸雄, 本橋和夫：日食工誌, 24 , 372 374 (1977).

12）山口直彦，平野真由美，山口幸寛：同上 $\mathbf{3 4}, 282 \sim 287$ (1987).

13）青山 稔, 丸山武紀, 兼松 弘, 新谷 勛, 塚本正人, 東 海林 茂, 松本太郎：油化学 34, 123 127 (1985).

14）堤 将和, 安井紀久代, 松岡麻男, 渡辺忠雄：食衛誌１9, 190 194 (1978). 